4. Tkachuk, N.A. (2019). Democratic civilian control in the field of cybersecurity. Criminal threats in the security sector: practices of effective response: materials of the panel discussion. [in Ukrainian]

5. Kruk, S.I. (2019). Development of public administration in the field of national security: from planning to control. Bulletin of the National University of Civil Defense of Ukraine. Public Administration Series, 2 (11), 37-43. [in Ukrainian].

6. Shopina, I.M. (2011). Regarding the legal regulation of the functioning of central executive bodies. Public law, 3, 65-71. [in Ukrainian].
7. Koropatnik, I.M. (2016) Interaction of civil society and the Armed Forces of Ukraine: administrative and legal principles: a monograph. [in Ukrainian].

8. Ostapenko, I.O. Features of proceedings in cases of military administrative offenses. Modern problems of administrative law and process: thesis add. participants All-Ukrainian scientific-practical conf., 251-254. [in Ukrainian].

Надійшла до редколегії 20.07.21

D. Degtyarov, Senior Lecturer

mega.degdd@ukr.net

ORCID ID 0000-0002-2512-6967

Taras Shevchenko National University of Kyiv, Kyiv, Ukraine

\title{
BODY OF DEMOCRATIC CIVILIAN CONTROL OVER THE DEFENSE FORCES
}

The purpose of writing this article is to define the concept and features of democratic civilian control over the defense forces.

It was found that the legal relations that arise during the consolidation and definition of the subject of democratic civil control are complex and governed by the rules of various branches of law. To correctly determine the subject of the studied type of control, it is necessary to distinguish the external manifestations of activity of these officials, which are subject to measurement, generalization and analysis. One such manifestation is the behavior of persons subject to legislative provisions on the exercise of democratic civilian control over the defense forces. The subject of democratic civilian control over the defense forces is an element of the objects of control, which is directly covered by the organizational behavior of both military officials and other categories of servicemen and employees of military formations, as well as civilians empowered by Ukrainian law to make decisions. relating to the defense forces. The subject of democratic civilian control over the defense forces must meet the following requirements: objectivity, measurability, specificity, repeatability of results in the case of application by other subjects of control of the same control methodology. The subject of democratic civilian control over the defense forces has its source in the social relations that arise in the security and defense sector. The relationship between the object and the subject of the specified control is determined by the scale of activities carried out to achieve the objectives of control. At the same time, the subject of democratic civilian control over the defense forces is always smaller in scale than its object. An analysis of the current legislation governing the control of the defense forces shows that a sufficient legal basis for the implementation of the above requirements has not yet been created. Gaps in the legal regulation of security and defense control activities need to be filled. This requires amendments to the Law of Ukraine "On National Security", aimed at specifying the system of evaluation of the results of control over the activities of the defense forces.

Keywords: democratic civil control, defense forces, security and defense sector, legal support, legal regulation, object of control, subject of control, subjects of control.

УДК 342.9

DOI: https://doi.org/10.17721/1728-2217.2021.47.51-53

О. Зіборєва, асп.

ORCID ID 0000-0001-7566-4600

Міжрегіональна Академія управління персоналом, Київ, Україна

\section{ФОРМИ ПУБЛІЧНОГО АДМІНІСТРУВАННЯ ПІДГОТОВКИ КАДРІВ 3 ВИЩОЮ ВІЙСЬКОВОЮ ОСВІТОЮ ДЛЯ ЗБРОЙНИХ СИЛ УКРАЇНИ}

Запропоновано визначення поняття і видів форм публічного адміністрування підготовки кадрів 3 вищою військовою освітою для ЗСУ як способи зовнішнього вираження досягнення поставлених перед суб'єктами публічного адміністрування у вказаній сфері цілей, здійснювані правовими та позаправовими (організаційними) методами. Проаналізовано теоретичні підходи до проблеми сутності форм публічного адміністрування, виокремлено найбільш важливі їхні ознаки. Такі форми з урахуванням принципу розмежування за характером та правовою природою поділено на чотири основні види: а) нормотворча діяльність, спрямована на встановлення та конкретизацію прав, обов'язків та відповідальності суб'єктів навчального процесу у ВВН3 та військових навчальних підрозділах закладів вищої освіти; б) видання виконавчо-розпорядчих та правозастосовчих індивідуальних правових актів; в) здійснення юридично значущих дій з виданням офіційного документа; г) здійснення забезпечувальних дій, необхідних для підтримки діяльності з підготовки кадрів з вищою військовою освітою для ЗСУ (сюди належить широкий комплекс діяльності, пов'язаної з організаційно-управлінським, інформаційним, матеріально-технічним, кадровим, психологічним та іншими видами забезпечення підготовки офіцерських кадрів). Обгрунтовано, що форми публічного адміністрування підготовки кадрів з вищою військовою освітою для ЗСУ є невід'ємною частиною понятійного апарата публічного адміністрування в секторі безпеки та оборони. Онтологічна природа досліджуваних форм публічного адміністрування зумовлена необхідністю практичної реалізації правових приписів на нормативно-правовому та індивідуальному рівні для досягнення цілей правового регулювання (забезпечення обороноздатності держави шляхом підготовки необхідної кількості офіцерських кадрів, що мають необхідні для цього знання, вміння, навички та особисті якості). Обґрунтовано, що напрями подальших наукових досліджень мають охоплювати проблеми, які виникають під час реалізації правових та позаправових (організаційних) форм публічного адміністрування підготовки кадрів з вищою військовою освітою для ЗСУ, а також шляхи розв'язання вказаних проблем.

Ключові слова: публічне адміністрування, форми публічного адміністрування, підготовка кадрів, зсу, вища військова освіта, правові форми, позаправові форми, правове регулювання.

Постановка проблеми. За результатами огляду системи військової освіти в Міністерстві оборони України (2020) було встановлено, що наразі система військової освіти перебуває у фазі інтенсивної трансформації. Амбітне завдання - у максимально стислі строки досягти достатньої сумісності зі структурами держав-членів Альянсу, осучаснити бачення подальшого розвитку військової освіти - стимулює до пришвидшення імплементації стандартів НАТО, зокрема й у сфрері військової освіти і науки. Вмотивований прогнозованим кар'єрним зростанням та фахово компетентний військовослужбовець - запорука побудови сучасного професійного війська [1]. Вказане потребує активізації наукових досліджень, спрямованих на пошук оптимальних форм публічного адміністрування підготовки офріцерських кадрів для ЗСУ, результати яких знайшли б своє втілення у законотворчій роботі, й обумовлює актуальність та важливість теми цієї статті.

Аналіз останніх досліджень і публікацій. Проблематику сутності та структури форм публічного адміністрування розглядали у своїх роботах такі науковці, як: В. Біла, К. Бугайчук, В. Галунько, В. Колпаков, О. Кузь- 
менко, О. Навроцький, І. Яковлєв та інші автори. Ці дослідники запропонували дефініції поняття "форма публічного адміністрування", ознаки вказаних фрорм, а також класифікації правових явищ, які можна вважати формами публічного адміністрування. Разом з тим, виходячи із предметної спрямованості досліджень цих науковців, предметом їх наукового пошуку ще не були форми публічного адміністрування підготовки кадрів з вищою військовою освітою для ЗСУ. Отже, проблеми визначення сутності та елементного складу означених форм залишаються ще недостатньо дослідженими, що обумовлює актуальність теми цієї статті.

Метою статті $€$ визначення поняття та видів форм публічного адміністрування підготовки кадрів з вищою військовою освітою для ЗСУ.

Виклад основного матеріалу. Категорію "форма" у правових дослідженнях, виходячи із загальнофрілософрської методології наукового пошуку, традиційно розглядають у нерозривній єдності з категорією "зміст", при цьому форма як феномен пізнання та практики зазвичай розуміється як те, що надає структурованості змісту, обумовлює можливість його існування. У свою чергу, зміст постає як наповнення оболонки форми, як сукупність структурних одиниць, які, набуваючи певної форми, утворюють правові френомени різноманітної природи.

У правовій науці робилися численні спроби визначити поняття "форма публічного адміністрування". Зокрема, В. Біла сформулювала поняття правової форми публічного адміністрування як структурованого волевиявлення суб'єкта (відповідно до встановленої юридичної процедури об'єктивації в адміністративному праві), уповноваженого на виконання функцій публічного адміністрування, що зумовлює настання юридичних наслідків у матеріальних і процедурно-процесуальних відносинах. Такі наслідки виникають відповідно до сфери дії, юридичної сили та юридичного змісту владних велінь, визначених компетенцією суб'єкта волевиявлення та стадією механізму адміністративно-правового регулювання [2, с. 27]. На жаль, авторка не пояснює сутність процедури об'єктивації, а в науці адміністративного права та державного управління цей термін не усталений. Наприклад, у роботах з державного управління згадується, що "об'єктивація - це комплексний результат (позитивно-конструктивний або, навпаки, негативно-руйнівний)" [3, с. 51], однак, фундаментальні роботи щодо зв'язку об'єктивації та публічного управління, на жаль, відсутні. У цілому ж у багатьох галузях наукових знань (педагогіці, психології, соціології, фрілософрії) термін "об'єктивація" часто має негативну конотацію (напр., "об'єктивація - це засіб, який дозволяє легко і швидко змусити людей робити певні речі, які вигідні для виробників та маркетологів, оскільки використовують базові природні інстинкти" [4, с. 288]). Отже, використання терміну "об'єктивація" замість класичної для правових наук категорії "реалізація", що здійснюється шляхом виконання, використання, дотримання і застосування, уявляється нам не зовсім виправданим. Окрім того, на нашу думку, самого по собі волевиявлення, навіть "структурованого", недостатньо для настання правових наслідків. Для виникнення форми правового адміністрування потрібна не лише декларація волі чи намірів одного суб'єкта правовідносин, а й відповідні дії іншого (інших) суб'єктів правовідносин.

Інакше трактує форми публічного адміністрування О. Навроцький. Він визначає це поняття як "напрями та способи реалізації публічно-правового адміністрування прав дитини на підставі нормативно-правових актів, що здійснюється органами державної виконавчої влади, органами місцевого самоврядування шляхом виконавчорозпорядчої діяльності для втілення державної політики та законів України, а також міжнародних договорів щодо забезпечення прав дитини" [5, с. 143]. Як бачимо, автор трактує форми як напрями, що, на наш погляд, не зовсім точно, адже напрям $є$ вектором реалізації форми.

К. Бугайчук, який пише: "Форми публічного адміністрування в органах Національної поліції України - визначені нормативно-правовими актами та здійснювані в межах компетенції суб'єктів публічного адміністрування способи зовнішнього вираження їх діяльності, яка спрямована на впорядкування організаційної структури системи Національної поліції України, планування, підготовку, розробку та реалізацію управлінських рішень, організацію діяльності апарата управління, здійснення документального, інформаційного, кадрового, психологічного забезпечення діяльності органів та підрозділів Національної поліції з метою досягнення цілей, виконання завдань та реалізації функцій, покладених на органи Національної поліції. Ознаками форм публічного адміністрування в органах Національної поліції $є$ такі: вони $€$ певними способами зовнішнього вираження діяльності суб'єктів публічного адміністрування в органах Національної поліції; здебільшого застосування певних форм регламентовано нормативно-правовими актами; вони застосовуються з метою виконання завдань та реалізації функцій, покладених на органи та підрозділи Національної поліції; за своєю суттю $є$ внутрішньо-системними, адже стосуються регламентації та оптимізації діяльності системи Національної поліції України; форми адміністрування визначаються та застосовуються в рамках компетенції певного суб'єкта адміністрування; вони тягнуть за собою певні юридичні наслідки для об'єктів управлінського впливу; обираються залежно від кінцевої мети, якої прагне досягти суб'єкт адміністрування" [6, с. 138]. Цей підхід вважаємо більш продуманим, у ньому враховано більшу частину невід'ємних ознак форм публічного адміністрування. Разом з тим у вищенаведеному підході не враховано основну, на нашу думку, ознаку форм публічного адміністрування: здійснення в його межах впорядкування суспільних відносин у межах компетенції суб'єкта публічного адміністрування шляхом здійснення таким суб'єктом нормотворчої діяльності. Для порівняння, так про це пише О. Сукманова: "форми публічного адміністрування - це зовнішній прояв адміністративної діяльності суб'єктів публічної адміністрації, що здійснюється на всіх рівнях публічного адміністрування щодо реалізації виконавчо-розпорядчої діяльності та надання адміністративних послуг із метою здійснення публічного адміністрування у певних сферах суспільства.

До форм публічного адміністрування охорони права власності в Україні належать: 1) видання адміністративних актів: підзаконних - щодо регулювання охорони права власності, індивідуальних - щодо виникнення, зміни та припинення права власності окремих осіб або створення персональних заходів охорони права власності; 2) укладення адміністративних договорів; 3) учинення інших юридично значущих адміністративних дій; 4) здійснення матеріально-технічних операцій (у т. ч., реєстраційних, які відіграють велику роль у сфрері права власності)" [7, с. 122-123].

На підставі вищевикладеного пропонуємо таке визначення форм публічного адміністрування підготовки кадрів з вищою військовою освітою для ЗСУ: способи зовнішнього вираження досягнення поставлених перед суб'єктами публічного адміністрування у вказаній сфері цілей, здійснювані правовими та позаправовими (організаційними) методами. Такі форми, з урахуванням запропонованого І. Яковлєвим принципу розмежування за характером та правовою природою [8, с. 102], виходячи 3 особливостей військово-правових відносин в освітній 
сорері [9, с. 147], можна поділити на чотири основні види, перші три з яких будуть мати правовий характер, а четверта - організаційний: а) нормотворча діяльність, спрямована на встановлення та конкретизацію прав, обов'язків та відповідальності суб'єктів навчального процесу у ВВНЗ та військових навчальних підрозділах закладів вищої освіти (напр., Положення про вищі військові навчальні заклади, затвердженого постановою Кабінету Міністрів України від 12 травня 2021 р. № 467; б) видання виконавчо-розпорядчих та правозастосовчих індивідуальних правових актів (напр., наказів про зарахування до ВВН3); в) здійснення юридично значущих дій $з$ виданням офіційного документа (напр., сертифіката про акредитацію освітньої програми, диплома бакалавра або магістра тощо); г) здійснення забезпечувальних дій, необхідних для підтримки діяльності з підготовки кадрів 3 вищою військовою освітою для ЗСУ (сюди належить широкий комплекс діяльності, пов'язаної з організаційноуправлінським, інформаційним [10], матеріально-технічним, кадровим [11], психологічним та іншими видами забезпечення підготовки офріцерських кадрів).

Висновки. Форми публічного адміністрування підготовки кадрів з вищою військовою освітою для ЗСУ $є$ невід'ємною частиною понятійного апарата публічного адміністрування в секторі безпеки та оборони. Онтологічна природа досліджуваних форм публічного адміністрування зумовлена необхідністю практичної реалізації правових приписів на нормативно-правовому та індивідуальному рівні для досягнення цілей правового регулювання (забезпечення обороноздатності держави шляхом підготовки необхідної кількості офріцерських кадрів, що мають необхідні для цього знання, вміння, навички та особисті якості).

Напрями подальших наукових досліджень мають охоплювати проблеми, які виникають під час реалізації правових та позаправових (організаційних) форм публічного адміністрування підготовки кадрів з вищою військовою освітою для ЗСУ, а також шляхи розв'язання вказаних проблем.

Список використаної літератури

1. Звіт про огляд системи військової освіти у Міністерстві оборони України. Національний університет оборони України імені Івана Черняховського. Київ, 2020. 154 с.

2. Біла В. Р. Правові форми публічного адміністрування в Україні : автореф. дис. ...докт. юрид. наук. 12.00.07. Київ, 2020. 40 с.

3. Мордвінов О. Г. Желябін В. О. Деякі підходи до оцінювання ефективності державного управління // Держава та регіони, 2009. №3. С.49-54

4. Астахова І., Косяк Д. Проблеми просування української продукції на зовнішніх ринках через явище об'єктивації у вітчизняній рекламі : мат-

O. Ziborieva, PhD Stud.

ORCID ID 0000-0001-7566-4600

Interregional Academy of Personnel Management, Kyiv, Ukraine

\section{FORMS OF PUBLIC ADMINISTRATION OF TRAINING}

\section{WITH HIGHER MILITARY EDUCATION FOR THE ARMED FORCES OF UKRAINE}

The purpose of this article is to define the concept and types of forms of public administration for training personnel with higher military education for the Armed Forces of Ukraine. The article analyzes theoretical approaches to the problem of the essence of the forms of public administration. The work highlights the most important features of these forms. The definition of the forms of public administration of personnel training with higher military education for the Armed Forces of Ukraine has been formulated: these are ways of external expression of the achievement of the goals set for the subjects of public administration in this area, carried out by legal and extra-legal (organizational) methods. Taking into account the principle of differentiation by nature and legal nature, it is proposed to divide such forms into four main types: a) rulemaking activities aimed at establishing and specifying the rights, duties and responsibilities of the subjects of the educational process in higher military educational institutions and military educational units of higher educational institutions; b) the publication of executive and administrative and individual legal acts; c) implementation of legally significant actions with the publication of an official document; d) the implementation of interim actions necessary to support the training of personnel with higher military education for the Armed Forces of Ukraine (this includes a wide range of activities related to organizational, managerial, informational, material and technical, personnel, psychological and other types of training for officer personnel). The article substantiates that the forms of public administration of training personnel with higher military education for the Armed Forces of Ukraine are an integral part of the conceptual apparatus of public administration in the security and defense sector. The ontological nature of the studied forms of public administration is due to the need for the practical implementation of legal prescriptions at the legal and individual level to achieve the goals of legal regulation (ensuring the defense capability of the state by training the required number of officers who have the necessary knowledge, skills, skills and personal qualities).

Keywords: public administration, forms of public administration, personnel training, the Armed Forces of Ukraine, higher military education, legal forms, extra-legal forms, legal regulation. 